\title{
The Correlation of Teachers' Reinforcement and Students' Achievement in English Learning Process
}

\author{
Nurul Hidayati Fajrin ${ }^{1}$, Martin Kustati ${ }^{* 2}$, Luli Sari Yustina ${ }^{3}$ \\ 1, 2, 3 UIN Imam Bonjol Padang, Indonesia \\ *Correspondence address Email: martinkustati@uinib.ac.id \\ E-mail: ${ }^{1}$ nurul12@gmail.com;; ${ }^{3}$ lulyregar@gmail.com
}

DOI: https://doi.org/10.15548/turast.v7i1.345

(Diterima: 31 Januari 2019. Disetujui: 24 Juni 2019. Diterbitkan: 30 Juni 2019)

\begin{abstract}
Abstrct
The study aims to identify teachers' reinforcement in English Learning Process at Senior High School 1 Padang. Teachers have to do several actions in the class such us encouragement, reinforcement, reward, and punishment. It was focused on positive and negative reinforcement that used in English Learning Process and any significant correlation of teacher' reinforcement and students' achievement. A quantitative research was used where the data taken from questionnaire. The data was analyzed by using Pearson correlation. The finding is that there is significance correlation of teachers' reinforcement and students' achievement in English Learning Process. All of the teachers are expected that using reinforcement in English Learning Process due to increased the students' achievement. It is concluded that positive reinforcement is mostly used by English teacher at Senior High School 1 Padang.
\end{abstract}

Keywords: Teachers' reinforcement, students' achievement, learning process

\section{INTRODUCTION}

The teacher is one of important elements in education because in the teaching and learning process they transferred the knowledge to the students. According to (oud, Cohen, \& Sampson (2014); Byram, Gribkova, \& Starkey (2002); Byram et al., (2002); Hargreaves (2000), learning process itself is interaction in classroom and the teacher has to be able to do the roles to create enjoyable situation and create the optimal interaction.
In addition, classroom interaction should be built in two spaces, among of students between students and teacher run well. It is supported by Chin (2006); Dabbagh \& Kitsantas (2004); Picciano (2002); Reaburn, Muldoon, \& Bookallil (2009); Swan (2001); Zeichner (2010) state that interaction is built in these spaces: the interaction between teacher and students; students and students; and students and instruction sources. The above spaces are helpful to gain the learning objective. 
Moreover, the teacher expects that learning materials which are taught can be understood completely. Gaining that purpose is not an easy job, because the students have different interest, potential, intelligence, and effort. Because of differences, the teacher has to be able to give the equal treatment to all students without any exception; therefore, the teaching learning process can make the students active physically and interact with other students, the teacher and the learning sources physically.

A good learning process is the process that can make the students study well. According to Fullan (2001), the best teacher of ten myths good teacher is a teacher who is able to create fun for students to learn. It means that the good teacher has good character and can make students enjoy in classroom. For example, the teacher can create the learning situation, thus the students study optimally.

Furthermore, interaction between the teachers and the students should be appropriate interaction due to it will build good relationship each other (Ahmad \& Sahak, 2009; Biggs, 1989; Chin, 2006; Goldenberg, 2008; So \& Brush, 2008; Tu \& McIsaac, 2002). It means that interaction among the teachers and the students can be built by giving punishment, reward, and reinforcement. They are the kinds of interaction that can be used by the teacher in the classroom.

In addition, the interaction that happen will make situation in classroom can be controlled and managed, because it shows the communication and feedback in each other. It is clear stated that reinforcement is one of kind of interaction in the classroom, so that the teacher has to know how to use interaction especially in giving reinforcement; the teacher has to know how and when the teacher reinforce the students. The teacher gives the reinforcement to students to make them feel competence. Furthermore, in the learning process, there are several things that can motivate students, namely reward, punishment, reinforcement, and encouragement.

In teaching and learning process, the students need to know what they have done is right or not, in order to make students will have knowledge from what they have done, because of that the teacher has to interact with the students appropriately. Furthermore, in the learning process, there are several things that can motivate students, namely reward, punishment, reinforcement, and encouragement.

Based UNESCO (2006) Punishment is an action (penalty) that is imposed on a person for breaking a rule or showing improper conduct. Punishment aims to control behavior through negative means. For example, when students do something wrong they will get punishment. But if the students do something good, they will get reward from the teacher.

Reid (2007:17) states that rewards are normally only successful in the short term and can help children who need a boost, particularly if they are finding a task challenging. Moreover, Brophy (2004) explain that reinforce as anything that increases or maintains the frequency of a behavior when access to it is made contingent on performance of that behavior. For example, careful work on assignments leading to successful task completion might be reinforced by giving verbal or written praise, 
awarding high grades, affixing stars or other symbols of excellence, allowing access to some privilege, awarding points that can be exchanged for prizes or applied to a competition, or in some other way compensating students for their efforts or recognizing them for their accomplishments by providing rewards that they value.

The last is encouragement, it is one of the part of interaction that can help the students to increase believed in their confidence to study the lesson. For example, when the teacher ordered the students to practice in front of the class, the teacher says, "I believe you can do it", "Don't give up" to appreciate them.

All of them are some of the learning interaction that can be used by teacher in the learning process to increase the students' motivation to study. But, in this research the researchers just focuses on the reinforcements. In ministry rule number 41 (2004) be explained that one of the requirement of Learning process is class management. One of the class managements' indicator is teacher gives reinforcement and feedback to students' responses and students' achievement as long as Learning Process.

Based on the observation that had been done by researchers in Senior High School 1 Padang, the researchers found that some teachers used reinforcement in English learning process. When the teacher order the students to practice in front of class, after they has done, the teacher giving the sentences "OK, Good", "very good", "thank you" and also give applause to appreciate them. When the teacher gives exercise to the students and after finishing, the teacher gives the sentences to appreciate them "OK, Good." The teacher gives the reinforcement to the students not only when the students made exercise and practice in front of the class, but also when the students do something.

Based on the phenomena above, the researchers are interested to do a research in Senior High School 1 Padang. It is because some teachers use various reinforcements in English learning process. Reinforcement is not used by one teacher only, but also many use reinforcement in English learning process. Reinforcement can increase the students' self-confidence and also stimulus the effort. The purpose of the research is to look for the correlation of teachers' reinforcement and students' achievement in English learning process at Senior High School 1 Padang. This research hopes that this research contributed positively to people. For the teacher, this research informed can implement the reinforcement in the school and the teacher can see which is the reinforcement used in the classroom view from the purposes and the teacher know what case the teacher can give reinforcement to the students because the students are glad if the teacher gives them reward or appreciation in the learning process.

This research informed about teacher' reinforcement in English learning process and informs the readers on how to be a good teacher to the students when the researchers is going to teach in the future and increase their knowledge about reinforcement and also they can do research about reinforcement in the other side or in the other school to get the different data about reinforcement. As a result, teacher should give reinforcement to the students because it can increase their 
self-confidence, motivation, and achievement in English learning process.

\section{METHOD}

This research is descriptive study. Because there was no treatment and experiment in this study, therefore the data gathered from this study not be effect by others, except the respondents themselves. In addition Gay (2000: 275) states that descriptive research involves collecting data in order to hypothesis of question concern to the correct status of the subject study. He also states that a descriptive study determines and describes the way things are. This study was correlation descriptive research.

This study involved collecting data in order to determine whether and to what degree a relationship exists between two or more quantifiable variables. It was useful to describe and find out the significance of the correlation between those two variables, variable $X$ and variable $Y$. The aim of the correlation research in this study was to determine the correlation between teachers' reinforcement and students' achievement in English learning process.

There were two kinds of variables in this research, the first variable was the teacher' reinforcement which seen from how teacher teach it was considered as independent variable (variable $\mathrm{X}$ ). The second variable was students' score which took from their teacher who taught them at the moment; it is considered as dependent variable (variable Y).

The respondents of this research are all the students at Class X MIA at Senior High School 1 Padang. There are 226 students of Class X MIA at Senior High School 1 Padang. They were separated to six classes. Simple random sampling was used to get the sample of respondent of this research.

Researchers took around $12 \%$ of population or 28 students. In getting the sample, the researchers used the piece of paper which numbered 4 part. The paper counted from 1- 4 and the other were blank. The last, piece of paper that numbered and the blank one gave to each class. The students who got paper that number count 1-4 would be sample of the research.

Instrument is tool that was used to collect the data. Instrument was used by researchers in this study was questionnaire and students' score. This method of data collection was quite popular, particularly in case of big enquiries. It was being adopted by private individuals, research workers, private and public organizations and even by governments.

Questionnaire is documents that ask the some questions of all respondent. Respondents recorded a written or typed response to each questionnaire item. Also, the respondents typically controlled the data-collection process: they could fill out the questionnaire at their convenience, answered the items in any order, took more than one sitting to complete it, made marginal comments, or skipped questions.

The questionnaire consists of a number of questions printed or typed in a definite order on a form or set of forms. The questionnaire is mailed to respondents who are expected to read and understand the questions and write down the reply in the space meant for the purpose in the questionnaire itself. The respondents have to answer the questions on their own. 
In this case, the researchers used close - ended Questionnaire. Whereas closed-ended questionnaires might be used to find out how many people use a service. Closed-ended questionnaires are probably the type with which you are most familiar. Most people have experience of lengthy consumer surveys which ask about your shopping habits and promise entry into a prize draw. The researchers used questionnaire to college the data and to know the activity about reinforcement that used by English teachers during teaching and learning process. The questionnaire was expected to figure out how the English teachers implement the reinforcement during teaching in the classroom. The researchers used questionnaire tools that can help the researchers to collect the data accurately.

The questionnaire consisted of 40 items, which were distributed into categories. Reinforcement consisted of positive and negative reinforcement. Positive reinforcement consisted of five indicators and 25 items, besides negative reinforcement consisted of four indicators and 15 items. Positive reinforcement belongs to natural and direct reinforcement, social reinforcement, activity reinforcement, tangible reinforcement, and token reinforcement. Besides, negative reinforcement consisted of delay the appreciation, do not give the appreciation, giving addition task, and show the unhappy expression. The questionnaires were given to 28 students at Senior High School 1 Padang Class X MIA. The questionnaire was return back to the researchers and no item were skipped or missed by the respondents. The responses to the items firstly were scored, and then the scores were recapitulated.
To gathering the data in the field, the researchers did some steps. The first, the researchers asked permission to the teacher to dispense the questionnaire sheet to students at Senior High School 1 Padang. Valid instruments used to collect the data. For ethical issue, the participants informed about the research and, therefore, their some in answering the questionnaire would not influence their school English achievement. However, their truly and honestly in answering the questions on the questionnaire was appreciated for the sake of valid research. Then the researchers had taken the students' score from the teacher. After getting the document, the researchers checked the assumptions of data.

Both of the data, questionnaires and document were administrated twice to class X MIA students of Senior high School 1 Padang. It was done twice in order to see the consistency of the respondents in answering the questions. Document was administrated first then followed by questionnaire. The result of administrating the questionnaire was expected to know the students' achievement if teachers used reinforcement in English Learning Process. Before they gave to students, the researchers explained about the use of the questionnaires that were going to be filled by them. In this activity, the researchers and the English teacher stayed in the classroom to watch the students who were answering the questionnaire and helping them when they found difficulties in responding the questionnaire.

The scores gained from the document and the questionnaire was correlated with statistical analysis. This result would be compared to the result 
of the test in order to get the correlation coefficient of the two variables. Both of the data were counted statistically in data analysis.

To know the level of score data gained, in this chase (in analyzing the data). Researchers had used Quantitative Measurement by count the total score, to know the frequency or percentage the teachers' reinforcement. It had been calculated by using formula from Sudijono (2001).

$$
\mathrm{P}=\frac{\mathrm{F}}{\mathrm{N}} \times 100
$$

Where:

P: Percentage of item

F: frequently of score

$\mathrm{N}$ : total questions

Besides, researchers also used SPSS to calculate mean and standard of deviation of tests with T-score of SPSS. Then, researchers tried to look at the correlation between two variables, namely; teacher' reinforcement and students' achievement used the Pearson Product Moment the technique to analyze the data, the formula used to estimate the correlation is:

$\mathrm{r}_{\mathrm{xy}}=\frac{n \sum x y-\left(\sum x\right)\left(\sum y\right)}{\sqrt{\left[n \sum x^{2}-\left(\sum x\right)^{2}\right]\left[n \sum y^{2}-\left(\sum y\right)^{2}\right]}}$

Where:

$$
\begin{aligned}
& \mathrm{r}_{\mathrm{xy}}=\text { the coefficient correlation } \\
& x=\text { the score of the teacher } \\
& \text { strategies } \\
& \mathrm{y} \quad=\text { the score of the students } \\
& \text { reading comprehension } \\
& \mathrm{n} \quad=\text { sample. } \\
& \Sigma x y=\text { the total scores of cross } \\
& \text { product } x y \\
& \Sigma \mathrm{x} \quad=\text { the sum of } \mathrm{x}
\end{aligned}
$$

$$
\begin{array}{ll}
\Sigma \mathrm{y} & =\text { the sum of } \mathrm{y} \\
\Sigma \mathrm{x}^{2} & =\text { the square of } \mathrm{x} \\
\Sigma \mathrm{y}^{2} & =\text { the square of } \mathrm{y}
\end{array}
$$

The result of the correlation is consult to the Product Moment table, if the correlation coefficient value (r) obtained is great or equal to the Product Moment $\mathrm{t}$-table value, the hypothesis is accepted, it means that there is a significant correlation between teachers' reinforcement and English learning process.

\section{RESULT AND DISCUSSION}

Based on the table correlation coefficient interpretation, it is found that the correlation between teacher' reinforcement and students' achievement at Senior High School 1 Padang is high, in the range $0.60-0.799$ which means that it has high correlation degree.

Based on this accepted hypothesis, it is also found that the higher the teacher' reinforcement is the higher the students' achievement. On the other hand, the lower the teacher' reinforcement is the lower the students' achievement also.

Based on the result of the research, the researchers found that the teacher mostly used positive reinforcement. The indicators of positive reinforcement that used by teacher are natural and direct reinforcement and social reinforcement.

Furthermore, the researchers found that hypothesis which says that there is a significant correlation between teacher' reinforcement and students' achievement" is accepted. It is proved that the $t_{\text {obtained }}(r=0.623)$ is higher than 
$r_{\text {table }}\left(r_{\text {table }}=0.374\right.$ at level of significance $0.05)$, it shows that $r_{\text {value which is }}$ obtained is bigger than $r_{\text {table. In this case, }}$ the alternative hypothesis is accepted. Besides that, in the table of $r_{\text {interpretation, }}$ the $t_{\text {value }}$ which is obtained located in the range between $0.600-0.799$ which indicates that teacher' reinforcement and students' achievement havae high correlation.

As Daymut (2009) explains that with positive reinforcement you may notice more than an increase of a behavior - you may notice an increase in self-esteem, an increase in motivation, and an increase in gratitude." It can be proved from the result of the document analysis that had gotten and calculated before. Because the students got high motivation, so that's way, the students were diligent to study. Thus, their achieving can be increased.

This means that the high score of teacher' reinforcement is always/ usually used in English Learning Process. The result of this study goes with the theories that reinforcement is very important to increase students' motivation in Learning. If students have high motivations to study, commonly they will get the good achievements. It is supported by Diedrich (2010) said that the appropriate use of positive reinforcement and behavior modification are important to success in the classroom, as frequent reprimands, low expectations, and infrequent praise offer result in students who exhibit challenging behaviors. It means that the positive reinforcement is very important in learning process, especially in English classrooms.

The result obtained is satisfying. After computing the data that had gotten from the field, it can be concluded that all of the reinforcements used by English teachers. But the mostly used was positive reinforcement especially natural and direct reinforcement and also social reinforcement. Moreover, there is high significant correlation between teachers' reinforcement and students' achievement at Class X MIA Senior High School 1 Padang.

\section{CONCLUSION RECOMMENDATION}

AND

It is concluded that teachers' reinforcement that mostly used in English Learning Process is Positive reinforcement, namely natural and indirect reinforcement and social reinforcement. Positive reinforcement was mostly used by English Teachers at Senior High School 1 Padang. The high categories in positive reinforcements were natural and direct reinforcement and also social reinforcement.

Moreover, based on the students' achievement, after calculating through Pearson Product Moment, the result shows that there is high significant correlation of teacher' reinforcement and students' achievement at Senior High School 1 Padang. It means that, if teacher always use the reinfoecement, students' achievement will be increase. And if the teacher seldom use the reinforcement, students achievement also dicreased.

Based on the conclusion of this research, it is also leads to some suggestion especially for English teachers, Candidate of teachers, commonly readers. These suggestions are also expected to be useful for the coming researchers, curriculum designer and particularly English teachers.

For English teacher, the use of teacher' reinforcement is useful for students in 
increasing students' achievement. In this case, the teacher are recommended to encourage the low achiever students to use reinforcement which most frequently used by high achievement students.

\section{REFERENCES}

Ahmad, A., \& Sahak, R. (2009). TeacherStudent Attachment and Teachers'attitudes towards Work. Journal of Educators $\mathcal{E}$ Education/Jurnal Pendidik Dan Pendidikan, 24.

Biggs, J. B. (1989). Approaches to the enhancement of tertiary teaching. Higher Education Research and Development, 8(1), 725.

Boud, D., Cohen, R., \& Sampson, J. (2014). Peer learning in higher education: Learning from and with each other. Routledge.

Brophy J. 2004. Motivating Students to Learn. London.

Byram, M., Gribkova, B., \& Starkey, H. (2002). Developing the intercultural dimension in language teaching: A practical introduction for teachers. Language Policy Division, Directorate of School, Out-of-School and Higher.

Chin, C. (2006). Classroom interaction in science: Teacher questioning and feedback to students' responses. International Journal of Science Education, 28(11), 1315-1346.
Dabbagh, N., \& Kitsantas, A. (2004). Supporting self-regulation in student-centered web-based learning environments. International Journal on ELearning, 3(1), 40-47.

Dawson Catherine, 2002. Practical Research Methods A user-friendly guide to mastering research techniques and projects, United Kingdom.

Daymut, J. A. M.A., CCC-SLP. 2009. Super Duper ${ }^{\circledR}$ Publications. www.superduperinc.com.

Diedrich, J., L., (2010).Motivating Students Using Positive Reinforcement.. Education and Human Development Master's Theses.

Fullan, M. (2001). The new meaning of educational change. Routledge.

Gavin R. (2007). Motivating Learners in the Classroom: Ideas and Strategies, London.

Goldenberg, C. (2008). Teaching English language learners: What the research does-and does not-say.

Hargreaves, A. (2000). Mixed emotions: Teachers' perceptions of their interactions with students. Teaching and Teacher Education, 16(8), 811-826.

Picciano, A. G. (2002). Beyond student perceptions: Issues of interaction, presence, and performance in an online course. Journal of Asynchronous Learning Networks, 6(1), 21-40. 
Reaburn, P., Muldoon, N., \& Bookallil, C. (2009). Blended spaces, work based learning and constructive alignment: Impacts on student engagement. Same Places, Different Spaces, 820-831.

So, H.-J., \& Brush, T. A. (2008). Student perceptions of collaborative learning, social presence and satisfaction in a blended learning environment: Relationships and critical factors. Computers $\mathcal{E}$ Education, 51(1), 318-336.

Sudijono A. (2001) Pengantar Statistik Pendidikan. Jakarta.
Swan, K. (2001). Virtual interaction: Design factors affecting student satisfaction and perceived learning in asynchronous online courses. Distance Education, 22(2), 306-331.

$\mathrm{Tu}$, C.-H., \& McIsaac, M. (2002). The relationship of social presence and interaction in online classes. The American Journal of Distance Education, 16(3), 131-150.

Zeichner, K. (2010). Rethinking the connections between campus courses and field experiences in college-and university-based teacher education. Journal of Teacher Education, 61(1-2), 89-99. 
